\title{
Cod-liver oil as both source and antagonist of vitamin $\mathbf{E}$
}

\author{
By T. MOORE, I. M. SHARMAN AND R. J. WARD \\ Dunn Nutritional Laboratory, University of Cambridge and \\ Medical Research Council
}

(Received 31 Fuly 1958)

Knowledge that cod-liver oil can be toxic when given in excess to various animals dates back to observations by Agduhr (1926). Since about the same time the oil has been known to be deficient in vitamin $\mathrm{E}$, at least as judged by its ability to promote reproduction in rats. Thus although Nelson, Ohrbeck, Jones \& Taylor (1928) concluded that the oil contained enough vitamin $\mathrm{E}$ to allow reproduction, most other workers (Mattill, 1922; Evans \& Bishop, 1923; Hogan \& Harshaw, 1926; Sure, 1927) found that it failed to prevent sterility. Hartwell (1927), who observed delayed parturition and fatal uterine haemorrhage in rats receiving large amounts of cod-liver oil, ascribed these abnormalities to lack of vitamin $E$ in the oil.

Later investigations proved that cod-liver oil is not merely ineffective as a source of vitamin $\mathrm{E}$, but that it actually intensifies the severity of certain lesions associated with avitaminosis $\mathrm{E}$. Even before the role of vitamin $\mathrm{E}$ in preventing nutritional muscular dystrophy was fully recognized the ability of cod-liver oil to precipitate this lesion, particularly in herbivores, was well established (Madsen, McCay \& Maynard, 1932-3, I935). Later Morris (1939) and Shimotori, Emerson \& Evans (1939, I940) showed, in rabbits and guinea-pigs respectively, that $\alpha$-tocopherol could neutralize the tendency of cod-liver oil to cause muscular dystrophy. According to Mackenzie, Mackenzie \& McCollum (I94I), however, the ability of $\alpha$-tocopherol to prevent muscular dystrophy in rabbits was lost when it was administered within a short time of a dose of cod-liver oil, or when cod-liver oil was included in the diet. Presumably these workers were observing the same antagonism between vitamin $\mathrm{E}$ and cod-liver oil as was reported by Morris (1939), but this time with the oil in ascendancy.

Mattill (I938) suggested that the role of vitamin $\mathrm{E}$ in preventing muscular dystrophy was related to its power of checking autoxidation in animal fats (Cummings \& Mattill, 1930-I). Dam (I944a) noticed that the body fat of rats became brown when cod-liver oil was included as $20 \%$ of their diet. This brown colour, which could be prevented by $\alpha$-tocopherol, was shown to be associated with the formation of peroxides (Dam \& Granados, 1945). Further evidence of the production of muscular dystrophy by codliver oil, in calves under conditions pertaining in practical animal husbandry, was reported by Blaxter, Wood \& MacDonald (1953). According to Bruce (1950) the inclusion of only $2 \%$ cod-liver oil, in a diet containing $85 \%$ of whole grain cereals, caused failure of lactation in mice. The defect could be prevented by dosing with $\alpha$-tocopherol. Adequate dosing with various sources of vitamin $\mathrm{E}$ also allowed normal reproduction, as judged by the birth of live litters, in rats given cod-liver oil as $2 \%$ of 
their diet, and sometimes also as the vehicle for dissolving vitamin $\mathrm{E}$ concentrates (Bacharach, Allchorne \& Glynn, 1937).

Although cod-liver oil, in excessive amounts, undoubtedly precipitates vitamin E deficiency, evidence based on chemical tests has nevertheless accumulated to contradict the original hypothesis that this oil is devoid of vitamin E. Quackenbush, Gottlieb \& Steenbock (I94I), using the nitric-acid method of Furter \& Meyer (1939), found that cod-liver oil gave a colour reaction corresponding to the presence of $26 \mathrm{mg}$ tocopherols/roo g. They pointed out, however, that the Furter-Meyer reaction was given by numerous substances other than the tocopherols and suggested that this reaction of cod-liver oil might be ascribed to vitamins A and D. No such doubt was left, at least about the presence of tocopherols in another fish-liver oil, after experiments by Robeson \& Baxter (1943). From a distillate of the liver oil of the mangona shark they isolated $\alpha$-tocopherol, as characterized by its biological and antioxidant potencies, its colour reaction with ferric chloride and 2:2'-dipyridyl (Emmerie \& Engel, 1938), its ultraviolet absorption spectrum and the crystalline form and melting point of its palmitate. The concentration of $\alpha$-tocopherol was calculated to be $10 \mathrm{mg} /$ Ioo g oil. Later, cod-liver oil itself was examined by Brown (1953). In three samples he found $25 \cdot 6,30 \cdot 2$ and $32 \cdot 2 \mathrm{mg} \alpha$-tocopherol/100 g, on the assumption that vitamin $\mathrm{E}$ was the only chromogen remaining after carotenoids, vitamin $\mathrm{A}$ and sterols had been removed. Further examinations, by paper chromatography, indicated that this assumption was valid, although the chromatography does not appear to have been applied quantitatively.

In spite of the action of cod-liver oil as an antagonist to vitamin E, therefore, the presence in the oil of measurable amounts of the vitamin seems indisputable. It has remained possible, however, to discredit the value of the oil as a source of the vitamin, on the assumption that only traces are present, incapable in any circumstances of satisfying the requirements of the animal. Experiments seemed to be required, therefore, in which (I) the amounts of vitamin E supplied by a typical cod-liver oil, when included as a fixed proportion of the diet, would first be evaluated by chemical methods and (2) the adequacy of this intake, when supplied either in cod-liver or as pure $\alpha$-tocopherol, would be studied in relation to the minimal requirement of the animal. Such experiments, with the rat as the experimental animal, are described in the present paper.

\section{EXPERIMENTAL}

Chemical estimation of $\alpha$-tocopherol. The cod-liver oil used throughout our investigation was of high-grade medicinal quality, with no signs of staleness. $\alpha$-Tocopherol was estimated by a modification of the method of Green, Marcinkiewicz \& Watt (1955). About $3 \mathrm{~g}$ of the oil were saponified in the presence of pyrogallol (Tošić \& Moore, 1945), and the vitamin A was removed on a column of floridin earth that had been treated with stannous chloride and hydrochloric acid (Emmerie \& Engel, I938; Kjölhede, 1942). $\alpha$-Tocopherol was separated from other reducing substances on a two-dimensional chromatogram (Green et al. 1955). No tocopherol other than the $\alpha$-form was present. 
Biological tests. Cod-liver oil was usually included in a diet of the following percentage composition: casein (vitamin-free) 25 , sucrose 50 , cod-liver oil 10 , dried brewer's yeast $\mathrm{ro}$, minerals 5 . Vitamin $\mathrm{K}$ was supplied as $50 \mu \mathrm{g}$ of 2-methyl-1:4naphthoquinone weekly. In one experiment the oil was increased to $30 \%$, replacing an equal weight of sucrose.

For the rats not getting cod-liver oil 10\% of lard was substituted, the diet then having our standard formula for producing vitamin $\mathrm{E}$ deficiency. The lard was examined by chemical tests and found to be virtually devoid of tocopherols. Vitamin $\mathrm{K}$ was supplied as before, and in addition weekly doses of vitamin A acetate, rooo i.u., and of ergocalciferol, 60 i.u., were given. Animals required as positive controls received $2 \mathrm{mg}$ DL- $\alpha$-tocopheryl acetate weekly.

For a first experiment, lasting I44-I45 days, albino rats of both sexes were used. In this strain dental depigmentation is induced more readily by deficiency of vitamin $\mathrm{E}$ than in the piebald (Moore \& Mitchell, 1955). For a second experiment, in which the rats received their diets for $197^{-244}$ days, piebalds were used. This choice was advisable because most of our experience on the minimal requirement of the rat for vitamin $\mathrm{E}$ has referred to this strain. A third, short-term, experiment was carried out to test the potency of the unsaponifiable fraction of cod-liver oil as a source of vitamin E. For this purpose such piebald rats were used as were available, in a state of deficiency, at the time of the experiment. They had been deprived of vitamin E for about 7 weeks, by restriction either to the diet containing lard or to a diet consisting mainly of commercial white bread, deficient in vitamin E (Moore, Sharman \& Ward, 1958).

Lesions studied. With one exception the criteria used for the recognition of vitamin E deficiency were among those recently described (Moore, Sharman \& Ward, 1958).

(I) In haemolysis tests the percentages of haemolysis induced in vitro by dialuric acid were recorded.

(2) Dental depigmentation, in albino animals, was assessed by the method of Moore $\&$ Mitchell (1955). The upper incisors were inspected, and marked 2 for each normally brown tooth, I for each mottled or faintly brown tooth and $\circ$ for each white tooth. Thus the maximum score, for two normal teeth, was 4 marks. For two completely depigmented teeth the score was 0 .

(3) Brown discoloration of the body fat was recorded, in one experiment, as being either present or absent. In another experiment marks ranging from I to 4, according to the intensity of the colour, were recorded for fat in the omentum, adjoining the testes or uterus, and under the skin. The scores were then averaged for each rat.

(4) Degeneration of the testes was observed by inspection and weighing, and, in some instances, by the preparation of paraffin sections stained with haematoxylin and eosin.

(5) Brown discoloration of the uterus was marked as previously described (Moore, Sharman \& Ward, 1958).

(6) Renal histolysis was studied by removing and fixing a kidney after the carcass had been kept, at room temperature, for exactly $3 \mathbf{h}$ after death. Marking of the 
degree of histolysis, as seen in paraffin sections stained with haematoxylin and eosin, was according to the system of Moore, Sharman \& Symonds (1958), with a maximum score of 3 .

\section{RESULTS}

The vitamin $E$ content of cod-liver oil, as estimated chemically. When the chromatographic method, outlined above, was applied to our cod-liver oil, in fresh condition, the mean of duplicate estimations was $10 \cdot 2 \mathrm{mg} \alpha$-tocopherol/100 $\mathrm{g}$. No other form of tocopherol was present.

For reasons of convenience, supplies of diet were not made up fresh daily, but sufficient amounts were made to last I week. It was necessary, therefore, to make sure that the vitamin $E$ present in the oil was stable for this period, when the diet was stored in closed tins in a cool place. Analyses of the oil, extracted from the stored diet with ether, showed $9.7 \mathrm{mg} \alpha$-tocopherol/roo g oil, which was virtually identical with the value found for the fresh oil.

Intake of vitamin $E$ as cod-liver oil. In these experiments food intakes were not

Table I. Summary of past experiments on the minimal weekly doses of $D L-\alpha$-tocopheryl acetate necessary to prevent various lesions caused by vitamin $E$ deficiency in piebald rats

\begin{tabular}{|c|c|c|c|c|c|c|}
\hline \multirow[b]{2}{*}{ Lesion } & \multirow[b]{2}{*}{ Reference } & \multirow{2}{*}{$\begin{array}{c}\text { Period of } \\
\text { experi- } \\
\text { ment } \\
\text { (days) }\end{array}$} & \multirow{2}{*}{$\begin{array}{l}\text { No. and } \\
\text { sex of } \\
\text { rats in } \\
\text { group }\end{array}$} & \multicolumn{2}{|c|}{$\begin{array}{c}\alpha-\text { Tocopheryl } \\
\text { acetate }\end{array}$} & \multirow[b]{2}{*}{ L.esion* } \\
\hline & & & & $\mathrm{mg} / \mathrm{rat}$ & $\mathrm{mg} / \mathrm{kg}$ rat & \\
\hline $\begin{array}{l}\text { Haemolysis in } \\
\text { vitro }\end{array}$ & $\begin{array}{l}\text { Moore, Sharman \& Ward } \\
\text { (1953) }\end{array}$ & 117 & $\begin{array}{l}29 \\
29 \\
29\end{array}$ & $\begin{array}{l}0.125 \\
0.25 \\
0.5\end{array}$ & - & $\begin{array}{c}+ \\
+- \\
0\end{array}$ \\
\hline & Ward (1958) & $\begin{array}{r}\text { I } 34 \\
\text { I } 34\end{array}$ & $\begin{array}{l}30 \\
30 \\
30 \\
39\end{array}$ & $\begin{array}{l}1 \cdot 08 \\
1 \cdot 26 \\
0.44 \\
0.66\end{array}$ & $\begin{array}{l}3.0 \\
3.5 \\
2.0 \\
3.0\end{array}$ & $\begin{array}{l}+ \\
0 \\
+ \\
0\end{array}$ \\
\hline $\begin{array}{l}\text { Testes } \\
\text { degeneration }\end{array}$ & Moore et al. (1953) & 179 & $\begin{array}{l}20 \\
20\end{array}$ & $\begin{array}{l}\circ \\
0.25\end{array}$ & - & $\begin{array}{l}+ \\
0\end{array}$ \\
\hline & Ahmed (1957) & 130 & 30 & $\begin{array}{l}0.175 \\
0.35\end{array}$ & - & $\begin{array}{l}+ \\
0\end{array}$ \\
\hline & Ahmed (1957) & 140 & $60^{*}$ & - & $\begin{array}{l}0.6 \\
I \cdot 2\end{array}$ & $\begin{array}{l}+ \\
0\end{array}$ \\
\hline & Ahmed (I957) & 369 & 30 & $\begin{array}{l}0.35 \\
0.7\end{array}$ & - & $\begin{array}{l}+ \\
\circ\end{array}$ \\
\hline & Ward (1958) & 105 & 20 & $\begin{array}{l}0.175 \\
0.250\end{array}$ & - & $\begin{array}{l}+ \\
0\end{array}$ \\
\hline Brown uterus & Moore et al. (1953) & $\begin{array}{l}\text { I I } 7 \\
284\end{array}$ & $\begin{array}{l}29 \\
29 \\
29 \\
29\end{array}$ & $\begin{array}{l}0.125 \\
0.25 \\
0.125 \\
0.25\end{array}$ & $\begin{array}{l}- \\
- \\
-\end{array}$ & $\begin{array}{l}+ \\
0 \\
+ \\
0\end{array}$ \\
\hline & $\begin{array}{l}\text { Moore, Sharman \& Symonds } \\
\left(\mathrm{r} 95^{8}\right)\end{array}$ & 167 & $\begin{array}{l}3 \text { 우 } \\
3 \text { 우 } \\
3 \text { 우 }\end{array}$ & $\begin{array}{l}0 \\
0.25 \\
0.5\end{array}$ & - & $\begin{array}{c}+ \\
+- \\
0\end{array}$ \\
\hline & Ward (1958) & 105 & $\begin{array}{l}2 \text { 우 } \\
2 \text { 우 }\end{array}$ & $\begin{array}{l}0.25 \\
0.375\end{array}$ & - & $\begin{array}{l}+ \\
\circ\end{array}$ \\
\hline Renal histolysis & $\begin{array}{l}\text { Moore, Sharman \& Symonds } \\
\left(195^{8}\right)\end{array}$ & 167 & $3 q$ & $\begin{array}{l}0 \\
0.25\end{array}$ & - & $\begin{array}{l}+ \\
\circ\end{array}$ \\
\hline
\end{tabular}

* + , present; $\circ$, absent; +-, present, but slight. 
recorded. In our experience, however, the observed increases in weight in the animals given the diet containing cod-liver oil must have required mean daily food intakes, throughout the experiment, of about $16 \mathrm{~g}$ for males and $\mathrm{I} 4 \mathrm{~g}$ for females. When the diet contained $10 \%$ of the oil these intakes corresponded to about $\mathrm{I} \cdot \mathrm{I}$ and $\mathrm{I} \cdot 0 \mathrm{mg}$ $\alpha$-tocopherol/rat weekly.

Requirement for vitamin $E$ of rats given a diet containing lard. Assessment of the vitamin $\mathrm{E}$ requirement is complicated, even when the diet is kept constant, by the wide choice of criteria by which sufficiency might be judged. Table I summarizes results obtained in this laboratory in investigations extending over several years. In most of the experiments under review a wide range of doses was given, but entries in the table are restricted to those just below and above the minimum necessary to prevent the lesion in question. The effects of lower and higher doses were invariably consistent with the findings for the marginal doses. Further complications may arise from variations in the minimum requirement with age and sex. Thus Ahmed (r957) found that the amount required to prevent testicular degeneration in rats increased with age, even after growth had stopped. According to Ward (1958) male rats require somewhat higher doses than females for protection in the haemolysis test.

From Table $\mathrm{I}$ it appears that for preservation of a normal resistance to haemolysis in female rats a weekly dose of about $0.5 \mathrm{mg} \alpha$-tocopheryl acetate is necessary. For males the requirement is larger, to an extent greater than can be explained by their larger size, being about $1 \cdot 25 \mathrm{mg}$. Degeneration of the testes is generally prevented, at least over periods up to 6 months, by a weekly dose of $0.25 \mathrm{mg}$. For the prevention of brown discoloration of the uterus $0.25 \mathrm{mg}$ weekly was also found to be adequate in two experiments. In two other experiments, however, the requirement appeared to be slightly higher, falling within the ranges of $0.25^{-0.5} \mathrm{mg}$ and $0.25-0.375 \mathrm{mg}$. Finally, post-mortem renal histolysis was completely prevented by $0.25 \mathrm{mg}$ weekly, the lowest dose tried. It may be sufficiently accurate, for the purpose of the present communication, to take the requirements for preventing testicular degeneration, brown uterus and renal histolysis all as $0.25 \mathrm{mg} \alpha$-tocopheryl acetate weekly.

First biological test of vitamin $E$ potency of cod-liver oil: I44-145 days, albino rats. The results are given in Table 2 . It will be seen that the inclusion of $10 \%$ cod-liver oil in the diet was ineffective in preventing abnormal haemolysis or dental depigmentation. The tendency to renal histolysis was more pronounced than when the diet contained lard. The rats developed the brown pigmentation of the body fat that results from the giving of cod-liver oil and is known to be preventable by adequate dosing with vitamin E. Brown pigmentation of the uterus, however, was only slight, and the testes were normal.

In rats which received the diet with $30 \%$ cod-liver oil our findings were the same as above with the exception that the testes showed degeneration in two out of three rats and that the uterus showed no brown pigmentation.

In control animals, given a diet containing lard and without tocopherol, all the signs of avitaminosis E developed, with the exception of brown body fat. When the lard diet was supplemented with tocopherols the rats remained free from any signs of deficiency.

Second biological test: 197-244 days, piebald rats. The results are given in Table 3 . 


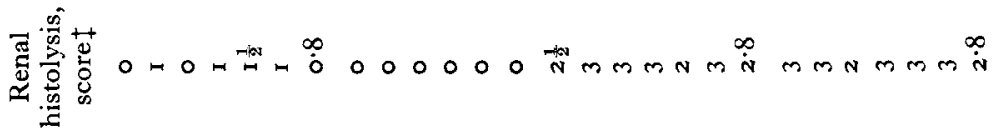

总

告

空

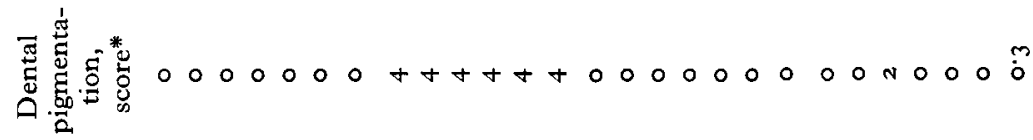

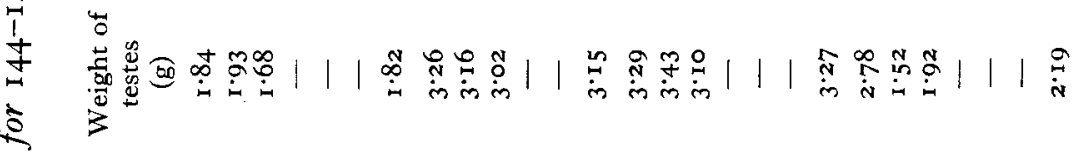

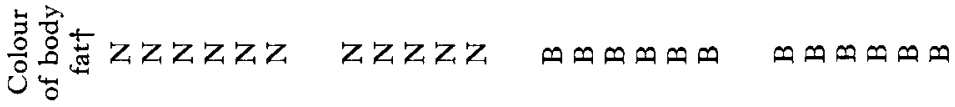

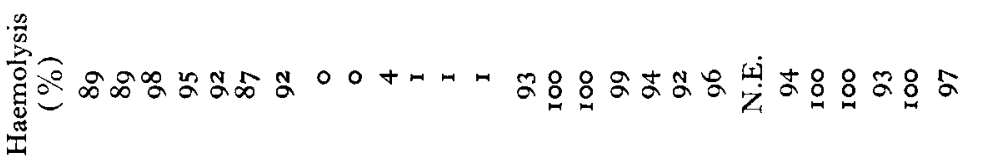

$\frac{\infty}{\infty}$

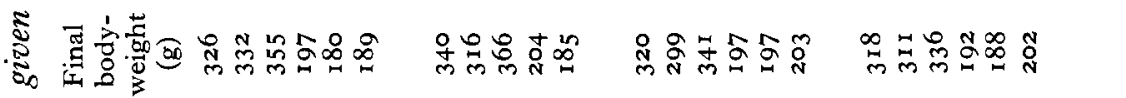

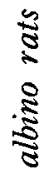

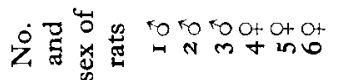

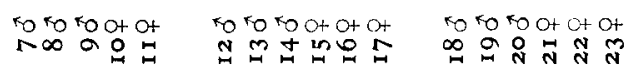

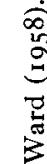

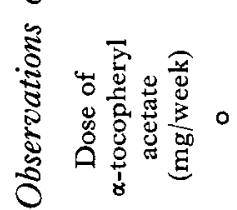

i

$\frac{0}{0}$

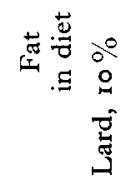

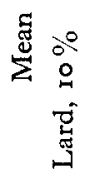

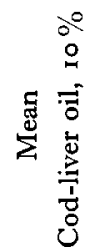

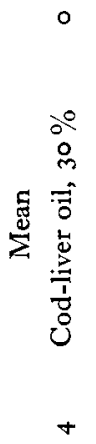

号ㅇ- 


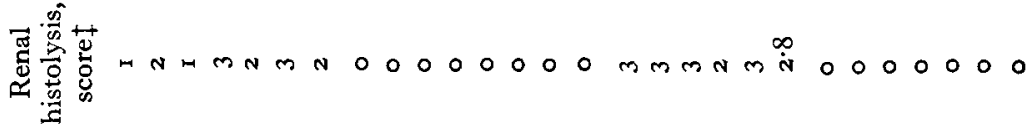

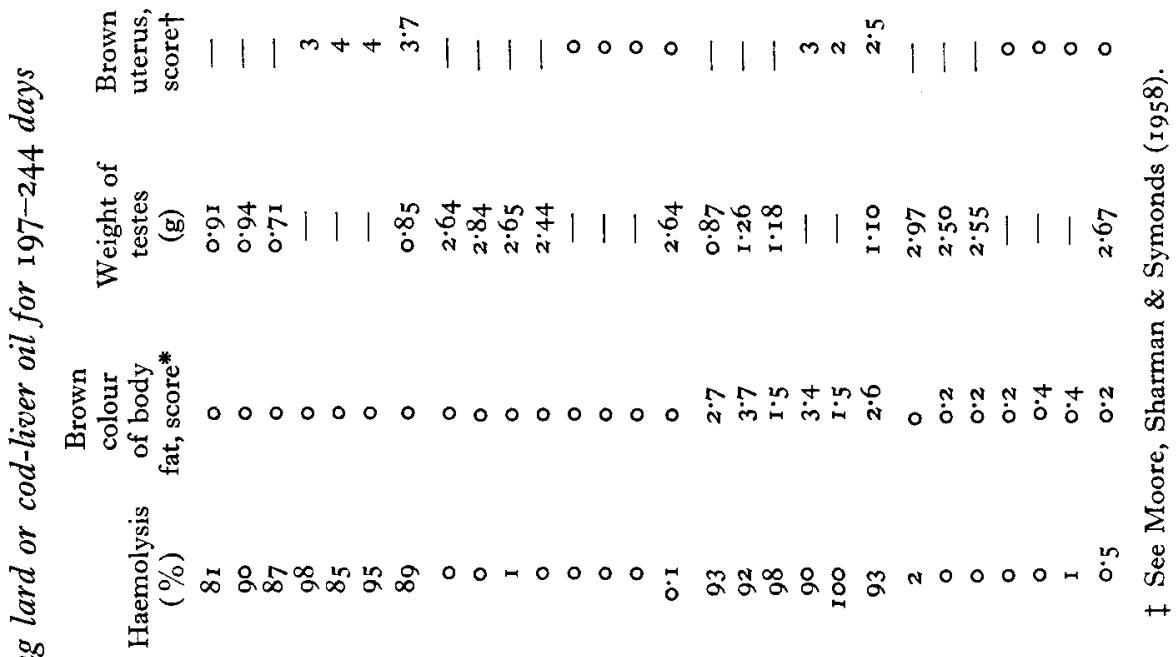

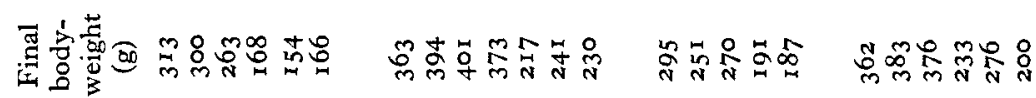

$\frac{\pi}{d}$

$\frac{2}{2}$

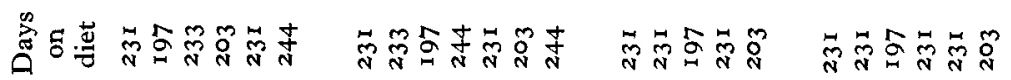

$\stackrel{2}{2}$

$\frac{\pi}{3}$

ह

$\dot{2}$

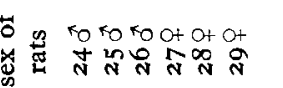

rotororoot ot Ot

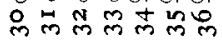

rororot of

rotolot ot

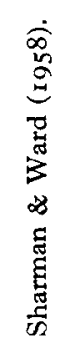

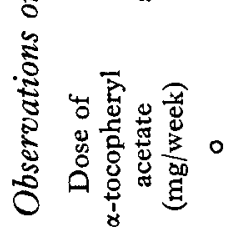

$\frac{0}{0}$

4

o

N

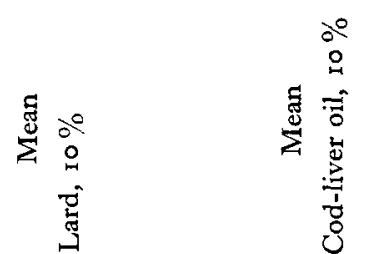

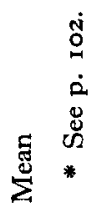

号号

$\infty$

$n$

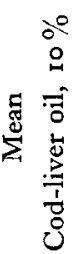

$\infty$ 
Again the inclusion of $10 \%$ cod-liver oil in the diet gave no protection in the haemolysis test or against renal histolysis. The body fat was brown. Moreover the testes, in contrast to our finding in the previous shorter experiment, were not protected. In the females the uteri were decidedly brown.

In animals given a diet containing lard, without doses of tocopherol, all the signs of avitaminosis $\mathrm{E}$ were again observed, with the exception of brown body fat. When doses of tocopherol were given as supplements to the diet containing lard, all signs of avitaminosis E were prevented. In animals given the cod-liver oil diet supplements of tocopherol prevented all abnormalities, except for very slight brown coloration in limited regions of the body fat.

The biological potency of the unsaponifiable fraction of cod-liver oil. The purpose of this experiment was to test the vitamin E activity of a concentrate of the oil, after the removal of the fatty acids known to antagonize the vitamin. The oil was saponified, and the unsaponifiable matter was passed through two columns of floridin earth in order to remove vitamin $\mathrm{A}$ and sterols. From $100 \mathrm{~g}$ oil $7.5 \mathrm{I} \mathrm{mg} \alpha$-tocopherol were recovered, as estimated chemically. For its administration to rats a solution in arachis oil was made, in such concentration that a dose of $75 \mu$. contained $\mathrm{I} \cdot 5 \mathrm{mg}$ $\alpha$-tocopherol.

Haemolysis tests were done on six rats. Five of the rats were deficient in vitamin $\mathrm{E}$, but one had been dosed regularly with DL- $\alpha$-tocopheryl acetate, $2 \mathrm{mg}$ weekly. From Table 4 it will be seen that in preliminary tests haemolysis was almost complete in the deficient rats, but virtually absent in the rat that had been dosed with tocopherol. Four of the deficient animals were then dosed with the unsaponifiable matter of cod-

Table 4. Haemolysis test on rats before and after a single dose of the unsaponifiable fraction of cod-liver oil

\begin{tabular}{|c|c|c|c|c|c|c|}
\hline \multirow[b]{2}{*}{$\begin{array}{l}\text { Rat no. } \\
\text { and sex }\end{array}$} & \multirow{2}{*}{$\begin{array}{l}\text { Days } \\
\text { on } \\
\text { diet }\end{array}$} & \multirow{2}{*}{$\begin{array}{l}\text { Final body- } \\
\text { weight } \\
\text { (g) }\end{array}$} & \multirow{2}{*}{$\begin{array}{c}\alpha \text {-Tocopheryl } \\
\text { acetate } \\
\text { (mg/week) }\end{array}$} & \multirow[b]{2}{*}{$\alpha$-Tocopherol* } & \multicolumn{2}{|c|}{ Haemolysis $(\%)$} \\
\hline & & & & & $\begin{array}{l}\text { Before } \\
\text { dosing }\end{array}$ & $\begin{array}{l}\text { After } \\
\text { dosing }\end{array}$ \\
\hline 48 ? & 58 & 220 & $\circ$ & $I \cdot 5$ & 89 & 0.2 \\
\hline 49 웅 & 58 & 167 & $\circ$ & $I \cdot 5$ & 86 & 0.9 \\
\hline 509 & $5 \mathrm{I}$ & 192 & $\circ$ & $I \cdot 5$ & 90 & $\mathrm{I} \cdot 3$ \\
\hline 519 & $5 I$ & 173 & o & $I \cdot 5$ & 84 & 0.0 \\
\hline $52 ?$ & $5 \mathrm{I}$ & 165 & $\mathbf{o}$ & 0 & 92 & $92 \dagger$ \\
\hline 539 & 52 & 198 & 2 & $\circ$ & $0.5 t$ & $I \cdot 6$ \\
\hline
\end{tabular}

liver oil, and haemolysis tests were repeated on all the animals $5 \mathrm{~h}$ later. Haemolysis was again almost complete in the deficient rat that had been left undosed, and absent in the rat dosed regularly with tocopherol. Changes in the percentage of haemolysis, however, were observed in all the four rats that had been dosed with the unsaponifiable matter of cod-liver oil. Instead of being almost complete, as formerly, haemolysis was now absent. Thus the vitamin $\mathrm{E}$ activity of the unsaponifiable matter was clearly demonstrated. 
DISCUSSION

The results show that whole cod-liver oil, in spite of containing substantial amounts of $\alpha$-tocopherol, has a limited value as a source of vitamin $\mathrm{E}$ for rats. The only signs of biological activity were found in our first experiment, when the inclusion of $10 \%$ of the oil in the diet appeared to give protection against degeneration of the testes and against brown uterus, although not against other abnormalities. Thus there was no protection in the haemolysis test, or against dental depigmentation or brown coloration in the body fat. Moreover the oil not only failed to check the liability to post-mortem renal histolysis, but increased the severity of this abnormality. Increasing the percentage of cod-liver oil in the diet, from ro to 3 , gave no better protection against the effects of vitamin $E$ deficiency: indeed the increase appeared to reduce the degree of protection afforded to the testes. In our second and longer experiment there was no evidence of protection by $10 \%$ of oil, even in the testes and uterus.

From the values found by chemical determination it is clear that the inclusion of 10\% cod-liver oil in the diet must have supplied our rats with about $\mathrm{r} \cdot 0 \mathrm{mg} \alpha$-tocopherol weekly throughout most of the experimental period. This amount is in fourfold excess of the dosage of $0.25 \mathrm{mg}$ weekly that is in our experience usually adequate to prevent all signs of avitaminosis E, except possibly abnormal haemolysis, in rats given a basal diet containing lard. Even in the haemolysis test the $\alpha$-tocopherol provided by the cod-liver oil should have sufficed for females, although perhaps not completely adequate for males. In the experiment in which the intake of cod-liver oil was raised to $30 \%$, the supply of $\alpha$-tocopherol must have been ten times greater than the minimum requirement for protection against most of the avitaminotic lesions in rats given the lard diet. It should also have been more than sufficient to prevent abnormal haemolysis in both sexes.

It seems clear, therefore, that cod-liver oil is a good source of vitamin $\mathrm{E}$ in a chemical sense, but that in biological tests the potency of the vitamin is more than neutralized by the presence of antagonists. If these antagonists are removed, as in our experiment on the action of the unsaponifiable matter of cod-liver oil in preventing abnormal haemolysis, the vitamin is able to exert its normal action.

From the observations of Dam ( $1944 b$ ) we know that highly unsaturated fatty acids can oppose the action of vitamin E. It seems safe to conclude that in cod-liver oil these substances are the main antagonists to vitamin E. A possible complication arises, however, from the presence in cod-liver oil of substantial amounts of vitamin A. Recently Irving (1958) has observed positive haemolysis tests in rats dosed with 15,000 i.u. vitamin A daily, in the form of a fish-liver oil concentrate, in spite of the simultaneous administration of $\alpha$-tocopheryl acetate, at the level of no less than $3 \mathrm{mg}$ daily.

Evidence that the result of interplay between vitamin $\mathrm{E}$ and its antagonists may vary in different tissues may be found in comparison between the brown colorations developed in the uterus and adipose tissues, particularly in our first experiment. In rats that got a diet containing lard, without supplements of vitamin E, a brown uterus was observed in contact with normal white fat deposits. In the rats that got cod-liver 
oil, however, the picture was reversed: the fat was decidedly brown, whereas the uterus was virtually normal. It appears, therefore, that some tissues are more vulnerable than others to antagonists of the vitamin. After more prolonged deficiency, we have seen, the antagonists predominated over the vitamin even in the uterus.

In our second experiment the administration of weekly doses of $\alpha$-tocopheryl acetate to rats given $10 \%$ cod-liver oil in their diet prevented all abnormalities, except for slight traces of brown coloration in parts of the body fat. This observation is in contrast with the report of Mackenzie et al. (I94I) that vitamin E may be inactivated in rabbits when it is administered in conjunction with a diet containing cod-liver oil. Probably the explanation of the conflicting findings in the two investigations lies in the differences in the magnitude of the dose of $\alpha$-tocopherol and in the species of animal used, and possibly also in the technique of feeding. In our experiment there was no organoleptic evidence that the cod-liver oil became rancid during storage in the diet, which agrees with our failure to observe any reduction in its tocopherol content.

As a general conclusion it seems evident that the vitamin $E$ requirement of the rat cannot be fixed on an absolute scale, since it varies over at least a tenfold range according to the nature of the dietary fat component. Presumably the effects of other nutrients, and particularly protein, have also to be considered, but their influence lies beyond the scope of this communication. As already stated, the requirement may also vary with the lesion under investigation.

\section{SUMMARY}

I. By chemical methods a specimen of medicinal cod-liver oil was found to contain about $10 \mathrm{mg} \alpha$-tocopherol/100 $\mathrm{g}$.

2. In biological tests of its vitamin $\mathrm{E}$ potency the cod-liver oil was included as $10 \%$ of the diet of growing rats. Control rats received a similar diet but containing lard, known to be devoid of vitamin $\mathrm{E}$.

3. In rats examined after restriction for several months to the diet containing codliver oil there appeared to be some delay in the development of brown uterus and of testicular degeneration. Other signs of vitamin E deficiency, including the increased liability to haemolysis and dental depigmentation, were not delayed. The tendency to rapid renal histolysis was intensified. Eventually, as the experimental period was prolonged, abnormalities occurred even in the uterus and testes.

4. In rats given the diet with $10 \%$ of cod-liver oil all the abnormalities caused by avitaminosis E, and also the brown coloration of the body fat caused by cod-liver oil, could be prevented by an adequate weekly dose of DL- $\alpha$-tocopheryl acetate.

5. Increasing the vitamin $\mathrm{E}$ intake by raising the percentage of cod-liver oil from Io to 30 did not prevent abnormalities due to avitaminosis $\mathrm{E}$.

6. In animals whose diet contained 10\% cod-liver oil the intake of $\alpha$-tocopherol provided in this form averaged about $1 \circ \mathrm{mg}$ weekly throughout the experiment. Previous experiments, on rats given a diet containing lard, had indicated that a weekly intake of $0.25 \mathrm{mg} \alpha$-tocopheryl acetate usually suffices to prevent all the lesions due to lack of vitamin $\mathrm{E}$, with the possible exception of the increased liability to haemolysis. 
7. A concentrate, prepared by the removal of the fatty acids of cod-liver oil after saponification, was found to have an activity in curing the increased liability to haemolysis in avitaminotic rats, consistent with its vitamin $\mathrm{E}$ content as estimated chemically.

8. The failure of whole cod-liver oil to act as a good source of vitamin $E$ in accordance with the results of chemical tests may therefore be explained by the antagonistic action of its other components, particularly its highly unsaturated fatty acids.

9. The vitamin $\mathrm{E}$ requirement of the rat cannot be fixed on an absolute scale, since it must vary over a wide range according both to the criterion of deficiency under investigation and also to the nature of the other components of the diet.

We thank Dr L. J. Harris for his valuable criticism, Mrs P. J. Richards, Mr B. J. Wayman and Miss E. Carman for caring for the animals, and Mr K. R. Symonds for histological assistance.

\section{REFERENCES}

Agduhr, E. (1926). Acta Paediat., Uppsala, 5, 165.

Ahmed, S. I. (1957). Reproductive organs of the male rat in deficiencies of vitamins E and A. Ph.D. Thesis, University of Cambridge.

Bacharach, A. L., Allchorne, E. \& Glynn, H. E. (1937). Biochem. F. 31, 2287.

Blaxter, K. L., Wood, W. A. \& MacDonald, A. M. (1953). Brit. F. Nutr. 7, 34.

Brown, F. (1953). Nature, Lond., I71, 790.

Bruce, H. M. (1950). F. Hyg., Camb., 48, 17x.

Cummings, M. J. \& Mattill, H. A. (1930-1). F. Nutr. 3, 42 I.

Dam, H. (1944a). F. Nutr. 27, 193.

Dam, H. (1944b). F. Nutr. 28, 297.

Dam, H. \& Granados, H. (1945). Acta physiol, scand. 10, I62.

Emmerie, A. \& Engel, C. (1938). Rec. Trav. chim. Pays-Bas, 57, 135 I.

Evans, H. M. \& Bishop, K. S. (1923). F. metab. Res. 3, $28 \mathrm{r}$.

Furter, M. \& Meyer, R. E. (1939). Helv. chim. acta, 22, 240.

Green, J., Marcinkiewicz, S. \& Watt, P. R. (1955). F. Sci. Fd Agric. 6, 274.

Hartwell, G. A. (1927). Biochem. F. 21, 1076.

Hogan, A. G. \& Harshaw, H. M. (1926). Res. Bull. Mo. agric. Exp. Sta. no. 8, p. 94.

Irving, J. T. (1958). Brit. F. Nutr. 12, 196.

Kjölhede, K. T. (1942). Z. Vitaminforsch. r2, 138 .

Mackenzie, C. G., Mackenzie, J. B. \& McCollum, E. V. (194I). F. Nutr. 21, 225.

Madsen, L. L., McCay, C. M. \& Maynard, L. A. (1932-3). Proc. Soc. exp. Biol., N. Y., 30, 1434.

Madsen, L. L., McCay, C. M. \& Maynard, L. A. (1935). Mem. Cornell agric. Exp. Sta. no. 178.

Mattill, H. A. (1922). F. biol. Chem. 5o, xliv.

Mattill, H. A. (1938). Int. physiol. Congr. xvi. Zürich, 2, I 12.

Moore, T. \& Mitchell, R. L. (1955). Brit. F. Nutr. 9, 174.

Moore, T., Sharman, I. M. \& Symonds, K. R. (1958). F. Nutr. 65, 183.

Moore, T., Sharman, I. M. \& Ward, R. J. (r953). Unpublished data.

Moore, T., Sharman, I. M. \& Ward, R. J. (1958). Brit. F. Nutr. 12, 2 × 5.

Morris, S. G. (1939). Science, 90, 424.

Nelson, V. E., Ohrbeck, E., Jones, R. L. \& Taylor, M. W. (1928). Amer. F. Physiol. 85, 476.

Quackenbush, F. W., Gottlieb, H. L. \& Steenbock, H. (1941). Industr. Engng Chem. (Industr.) 33, 1276.

Robeson, C. D. \& Baxter, J. G. (1943). F. Amer. chem. Soc. 65, 940.

Shimotori, N., Emerson, G. A. \& Evans, H. M. (1939). Science, 90, 89.

Shimotori, N., Emerson, G. A. \& Evans, H. M. (1940). F. Nutr. 19, 547.

Sure, B. (1927). F. biol. Chem. 74, 45 .

Tošić, J. \& Moore, T. (1945). Biochem. F. 39, 498.

Ward, R. J. (1958). Biochem. F. 69, 6 I $P$. 